\title{
Pelatihan Pemasaran dan Produksi serta Pendistribusian Makanan di Masa Pandemi Covid-19 pada Usaha Waralaba Makanan di Wilayah Depok Jawa Barat
}

\author{
Syahrudi*, Abdul Azim Wahbi \\ Universitas Indraprasta PGRI \\ andri84.septi@gmail.com
}

\begin{abstract}
Abstrak
Dalam mencegah dan menangani kondisi dan dampak wabah Covid-19 di Indonesia, maka dipandang perlu menjaga ketersediaan pangan olahan yang berkualitas bagi masyarakat Indonesia. Dalam melaksanakan praktik pemasaran produksi, distribusi dan ritel pangan olahan, kami sebagai dosen memandang perlu melakukan pelatihan dan penyuluhan tentang pemasaran serta pencegahan penyebaran Covid-19 dan memastikan penerapan sesuai dengan panduan selama masa pandemik Covid-19.Diharapkan dengan diadakannya pelatihan ini, pelaku usaha dapat menerapkan dengan baik sehingga dapat mencegah penyebaran Covid-19, dan penjaminan keamanan dan mutu pangan olahan dapat terus ditingkatkan Pengabdian kepada masyarakat yang akan dilaksanakan fokus pada pelaku usaha waralaba Rafiza Fried Chiken yang tersebar di wilayah Depok Jawa Barat sebagai target program dengan tujuan agar pelaku usaha UMKM mendapatkan pemahaman mengenai pelatihan pemasaran, pengolahan dan pendistribusian makanan yang aman dan berkualitas, sehingga pemahaman tersebut dapat diterapkan dalam kegiatan usaha serta dapat memperbaiki kualitas usaha yang sedang dijalankan.
\end{abstract}

Kata Kunci: pelatihan pemasaran, pendistribusian, pengolahan pangan di masa Covid-19

\section{Marketing and Production Training and Distribution of Food during Pandemi Covid-19 in Food Franchise Business in Depok Area of West Java}

\begin{abstract}
In preventing and handling the condition and impact of the Covid-19 outbreak in Indonesia, it is considered necessary to maintain the availability of quality processed food for the people of Indonesia. In carrying out marketing practices for the production, distribution and retail of processed food, we as lecturers consider it necessary to conduct training and counseling on marketing and prevention of the spread of Covid-19 and ensure implementation in accordance with the guidelines during the Covid-19 pandemic. It is expected that with this training, businesses can apply well so as to prevent the spread of Covid-19, and guarantee the safety and quality of processed foods can be continuously improved. Community service that will be implemented focuses on franchisees Rafiza Fried Chiken spread in Depok area of West Java as a target program with the aim that MSMEs businesses get an understanding of marketing training, processing and distribution of safe and quality food, so that the understanding can be applied in business activities and can improve the quality of business that is being run.
\end{abstract}

Keywords: marketing training, distribution, food processing during Covid-19

\section{PENDAHULUAN}

Pada Maret 2020 Pemerintah mengumumkan bahwa virus Covid-19 sudah masuk ke Indonesia. Akan tetapi sebenarnya para pakar epidemi sudah mengidentifikasi bahwa virus ini sudah masuk ke Indonesia sejak awal Januari. Hal ini terlihat dari data kematian yang terjadi di DKI Jakarta, di mana jumlah kematian pada Januari melebihi jumlah kematian dari bulan-bulan sebelumnya. Namun pemerintah mengumumkan bahwa identifikasi kasus pertama terjadi pada Maret yang mana terjadi karena penularan transmisi lokal dan bukan kasus penularan impor. Banyak yang beranggapan bahwa masuknya virus tersebut terjadi melalui pintu-pintu gerbang di beberapa wilayah Indonesia semisal masih 
Vol. 2, No. 2, July, 2021, pp. $97-105$

e-ISSN: 2722-2004

\section{Marketing}

and

Production

Training and

Distribution

of Food

during

Pandemic

Covid-19 in

Food

Franchise

Business in

Depok Area of

West Java

Syahrudi,

A. A. Wahbi

dibukanya bandara-bandara Indonesia sebagai akses masuk dan keluar bagi warga Negara asing yang ingin masuk dan keluar Negara Indonesia padahal di beberapa Negara sudah banyak menerapkan penutupan bandara-bandara internasional mereka guna mencegah masuknya virus tersebut ke Negara itu, tetapi pemerintah Indonesia merasa cukup hanya melakukan langkah-langkah antisipasi di antaranya menggunakan health alert card atau yellow card lalu thermal scanner untuk mengecek suhu tubuh di atas $38,5^{\circ} \mathrm{C}$ di pintu masuk dan keluar RI. Alhasil itu semua tidak cukup untuk mengantisipasi masuknya virus tersebut ke Indonesia. Tercatat sejak Maret hampir setiap hari terkonfirmasi kasus positif virus korona 19 dan data grafik menunjukkan semakin meningkat secara signifikan kasus tersebut di wilayah DKI Jakarta, Jawa Barat, Sulawesi Selatan, Sulawesi Utara, Jawa timur, Jawa Tengah. Dengan melihat kondisi ini dampak pada sektor ekonomi paling terlihat jelas bahkan usaha-usaha restoran tidak diperbolehkan bagi pengunjungnya untuk makan di tempat melainkan harus dibawa pulang lalu pusat perbelanjaan ditutup.

Semua aktivitas terdampak dan mencari bentuk untuk menyesuaikan terhadap situasi, sektor ekonomi terpukul atas kebijakan itu dan dampak itu paling dirasakan oleh para pengusaha-pengusaha restoran atau rumah makan tak terkecuali bagi pemilik rumah makan atau usaha makanan waralaba, yang jelasjelas mereka merasakan langsung dampak dari kebijakan ini di mana pendapatan mereka turun drastis hampir $80 \%$ sehingga yang terjadi adalah banyak para pengusaha restoran kecil dan waralaba yang menutup usaha mereka karena tidak mampu bertahan terhadap situasi ini.

Abdimas yang akan kami laksanakan fokus pada pelaku usaha waralaba makanan yaitu Rafiza Fried Chiken yang tersebar di wilayah Depok Jawa Barat. Tujuannya agar para pemegang usaha Rafiza Fried Chiken mendapatkan pemahaman mengenai pelatihan pemasaran pengolahan dan pendistribusian makanan yang aman sehingga mereka dapat bertahan pada kondisi seperti ini. Berikut data mitra bisnis Rafiza Fried Chiken yang tersebar di wilayah Depok Jawa Barat.

Table 1. Data Mitra Bisnis Rafiza Fried Chiken wilayah Depok Jawa Barat

\begin{tabular}{llll}
\hline No & \multicolumn{1}{c}{ Nama Resto } & \multicolumn{1}{c}{ Alamat } & \multicolumn{1}{c}{$\begin{array}{c}\text { Status } \\
\text { Mitra }\end{array}$} \\
\hline 1 & Rafiza Fried Chiken Limo & Jl. Artayasa No 121 Limo Depok & Pembinaan \\
2 & Rafiza Fried Chiken Citayam & Jl. Pintu Air Pabuaran Bj Gede Depok & Pembinaan \\
3 & Rafiza Fried Chiken Depok & Sentra Perdagangan Sukmajaya Depok & Pembinaan \\
4 & Rafiza Fried Chiken Gandul & Jl. H.Terin Gandul Depok & Pembinaan \\
5 & Rafiza Fried Chiken Cinere & Jl Bukit Cinere Depok & Berkembang \\
6 & Rafiza Fried Chiken Beji & Jl Mawar No 25 Beji Depok & Berkembang \\
7 & Rafiza Fried Chiken Gandul & Jl Erha Gandul Depok & Berkembang \\
8 & Rafiza Fried Chiken Beji & Jl. Tanah Baru Raya No 19 Depok & Pembinaan \\
9 & Rafiza Fried Chiken Kukusan & Jl. Kukusan Raya No 201 Depok & Pembinaan \\
\hline
\end{tabular}

Setelah memahami situasi yang terjadi akibat dari dampak Covid-19 dan kebijakan pemerintah maka dapat disimpulkan beberapa permasalahan mitra. Permasalahan tersebut dapat dilihat berdasarkan tabel berikut. 
KANGMAS: Karya Ilmiah Pengabdian Masyarakat, Vol. 2 No. 2, July 2021 - 99 http://journal.neolectura.com/index.php/kangmas

Tabel 2. Permasalahan Mitra Pelaksanaan Abdimas

Permasalahan Mitra bisnis Rafiza Fried Chiken

Aspek Strategi Pemasaran

Aspek Manajemen Usaha

Banyak mitra bisnis memandang pemasaran sebagai sesuatu yang mewah sehingga produk tidak mendapat sentuhan pemasaran dan promosi yang baik di masa pandemi Covid-19 ini.

Pengetahuan tentang pemasaran juga masih kurang sehingga para pengusaha mikro dan kecil hanya menjalankan metode penjualan secara tradisional saja. Imbasnya terjadi pada masa Covid-19 ini.

\begin{tabular}{ll}
\hline Tahap Persiapan & \\
\hline Pra-Survei & $\begin{array}{l}\text { Identifikasi permasalahan \& } \\
\text { (permasalahan spesifik yang dialami mitra). }\end{array}$
\end{tabular}

Pembentukan Tim PKM

Pembentukan Tim disesuaikan dengan jenis kepakaran untuk menyelesaikan permasalahan mitra.

Pembuatan Proposal

Koordinasi Tim \& Mitra

Pembuatan proposal untuk menawarkan solusi permasalahan \& penyediaan dana dalam pelaksanaan solusi bagi Mitra.

Perencanaan pelaksanaan program secara konseptual, operasional dan job describtion dari Tim \& Mitra.

Persiapan Alat \& Bahan Pembelian dan penyewaan alat serta pembuatan materi Pelatihan
Belum adanya pemahaman usaha khususnya protokol kesehatan sehing pelaku usaha belum dapat mengembangkan usahanya secara optimal di masa pandemi Covid-19 ini.

KANGMAS is a journal published by Neolectura, issued three times in one year. KANGMAS is a scientific publication media in the form of conceptual paper and field research related to social service work.

It is hoped that KANGMAS can become a media for academics and researchers to publish their social service work and become a reference source for the development of social and humanity.

Our focus: Social Service

Our Scope:

Humanities,

Education,

Management,

History,

Economics,

Linguistics,

Literature,

Religion,

Politics,

Sociology,

Anthropology,

and other social service works.

Tahap Pelaksanaan (Kegiatan Dilaksanakan di Lokasi Mitra)

Sosialisasi pengenalan

UKM dan legalitas merek

dalam kegiatan usaha

Sosialisasi nama dagang

sebagai strategi

pemasaran dalam kegiatan

usaha

Kegiatan dilaksanakan melalui pemaparan materi dan diskusi

(30 menit)

Kegiatan dilaksanakan melalui pemaparan materi dan diskusi

(30 menit)

Sosialisasi mekanisme

strategi pemasaran

pengolahan makanan

Kegiatan dilaksanakan melalui pemaparan materi dan diskusi

(30 menit)

Evaluasi Program

Dilakukan dengan membandingkan kondisi mitra sebelum dan sesudah pelaksanaan program. Indikator keberhasilan program dengan adanya perubahan positif dari mitra (perkembangan

usaha) setelah pelaksaan program

Pelaporan

Penyusunan laporan dilakukan sebagai bentuk pertanggung jawaban atas pelaksanaan program

untuk kemudian dilakukan publikasi 
Vol. 2, No. 2, July, 2021, pp. $97-105$

e-ISSN: 2722-2004

Rafiza Fried Chiken adalah sebuah bisnis dibidang kuliner khususnya di makanan fried chiken yang telah dirintis oleh dua orang, Rafiza pertama kali launching pada Mei 2018, di mana awal berdiri baru memiliki 1 outlet di wilayah Grogol Depok. Seiring berjalanya waktu, mitra-mitra Rafiza mulai bertambah dan saat ini sekitar 60 outlet yang sudah tersebar di area Jabodetabek, Bandung, Purbalingga, Batam, bahkan Tarakan. Konsep bisnis yang ditawarkan adalah harga franchise yang relatif terjangkau. Mulai dari harga 7 jutaan sudah mendapatkan paket franchise lengkap dari bahan baku, perlengkapan sampai alat masak sehingga mitra sudah bisa langsung menjalankan usahanya

\section{Marketing}

and

Production

Training and

\section{Distribution}

\section{of Food}

during

Pandemic

Covid-19 in

Food

Franchise

Business in

Depok Area of

West Java

Syahrudi,

A. A. Wahbi

\section{METODE PELAKSANAAN}

Tahapan kegiatan program abdimas dapat dilihat dalam beberapa metode yang digunakan pada pelaksanaan program, meliputi:

\section{Sosialisasi}

Program kegiatan abdimas dilakukan yang pertama adalah sosialisasi kepada mitra sehingga nantinya mitra akan mengetahui tujuan kita mengadakan abdimas, sosialisasi juga merujuk pada nantinya apa yang akan kita lakukan di sana yaitu dari seminar, pelatihan sampai pada praktik penerapan pelatihan dan simulasi dan ini akan membantu mereka nantinya untuk menyiapkan berbagai hal yang diperlukan nantinya dalam kegiatan ini.

\section{Pelatihan dan Diskusi}

Setalah mitra mengetahui kegiatan apa yang akan kita lakukan nanti melalui sosialisasi maka pada tahap pelaksanaan selanjutnya adalah melaksanakan program pelatihan yang telah direncanakan dalam program pelatihan ini materi yang disampaikan berupa program pemasaran dimasa pandemi Covid-19 ini sampai pada program produksi dan distribusi makanan pada masa Covid-19 ini setelah melaksanakan program-program itu maka dibuka forum diskusi yang tujuannya untuk berbagi permasalahan yang akan dihadapi dan solusi yang ditawarkan oleh mitra dari tim abdimas.

\section{HASIL DAN PEMBAHASAN}

Adapun hasil capaian program pengabdian kepada masyarakat yakni antara lain:

1. Meningkatkan pemahaman mitra pada kinerja pemasaran dan pengolahan makanan serta distribusi pada masa pandemi Covid-19.

2. Memperbaiki produksi baik pada lingkup proses pengolahan sehingga dihasilkan produk yang higienis dan layak bersaing dalam rasa dan harga di masa pandemi Covid-19 ini.

3. Memperbaiki media teknologi pemasaran dan distribusi melalui inovasi kemasan yang higienis dan bebas dari Covid-19. 
4. Peningkatan alat media pemasaran yang inovatif dan sederhana pemanfaatan teknologi media sosial sebagai alat pemasaran yang efektif dimasa pandemi Covid-19 ini.

Rincian pengabdian masyarakat dia awali dengan identifikasi dan analisis situasi. Identifikasi dan analisis situasi ini dilakukan dengan pelatihan dan diskusi tentang permasalahan yang dihadapi mitra akibat dampak dari pandemi Covid-19 ini dan dilaksanakan pada 1 November 2020-25 Desember 2020 pada mitra abdimas yang tergabung dalam anggota waralaba Rafiza Fried Chiken serta membahas mengenai permasalahan yang dihadapi mitra serta peluang yang menjanjikan dengan modal yang relatif kecil dan dalam menjalankan usahanya. dari hasil penggalian informasi yang didapat dari mitra abdimas tim mendapat beberapa masalah yang dihadapi mitra, permasalahan itu antara lain:

1. Mereka berbagi keluh dan kesah susahnya menjalankan usaha di masa pandemi Covid-19 ini dari berkurangnya pendapatan mereka sampai pada harga bahan baku yang tinggi.

2. Pada dasarnya mereka sudah memahami bahaya dari penularan Covid19 sehingga bagaimana caranya mereka bisa melakukan usaha dimasa pademic Covid-19 ini dengan menerapkan protokol kesehatan yang sudah ditentukan oleh pemerintah.

3. Ada keinginan dari mereka untuk beralih ke usaha lain tapi mereka tidak mempunyai kemampuan untuk melekukkannya karena sulitnya mereka bertahan di masa pandemi Covid-19 ini, keterbatasan skill dan informasi tentang jenis usaha baru yang akan mereka jalani

Dari permasalahan yang dihadapi oleh mitra tim mencoba untuk memberikan solusi bagaimana permasalahan itu nanti dapat diatasi dan mitra dapat meningkatkan hasil penjualannya di masa pandemi Covid-19 ini. Adapun solusi yang tim tawarkan kepada mitra adalah berupa pemasaran pengenalan dan memberikan informasi yang terkait dengan protokol kesehatan dalam menjalankan usaha.

\section{Pelatihan Pemasaran}

Adapun kegiatan yang dilakukan dalam pelatihan mencakup kegiatan pengenalan media pemasaran baik melalui media fisik di mana mitra dibantu dalam proses pemasaran media fisik menggunakan brosur, baliho, sampai pada membantu terjun langsung untuk menyebarkan brosur kepada masyarakat sekitar tempat usaha mitra dengan tujuan usaha mitra dapat berkembang nantinya. Kedua, pemasaran melalui media sosial yaitu di mana tim abdimas membantu mitra dalam membuat account media sosial sehingga mitra bias memasarkan produknya melalui media sosial berupa Facebook, Instagram, dll. Ketiga, membantu mitra dalam memasarkan produknya dengan menggunakan aplikasi ojek online maupun online shope di mana mitra dibantu untuk membuat account pada aplikasi-aplikasi tersebut sehingga wilayah pemasaran mitra menjadi lebih luas dan apa yang didapatkan oleh mitra nanti bias lebih memuaskan hasilnya.

\section{Pelatihan Produksi}

Pelatihan Produksi mencakup sanitasi pangan di mana sanitasi pangan merupakan upaya dalam mempertahankan pangan yang higienis dan bebas dari zat- 
Vol. 2, No. 2, July, 2021, pp. $97-105$

e-ISSN: 2722-2004

\section{Marketing}

and

Production

Training and

Distribution

of Food

during

Pandemic

Covid-19 in

Food

Franchise

Business in

Depok Area of

West Java

Syahrudi,

A. A. Wahbi

zat yang bisa membahayakan tubuh. Dalam sanitasi pangan diterapkan beberapa hal yaitu:

\section{a. Penerapan cara produksi yang baik}

Bahan dasar produksi makanan bersumber dari hasil pangan yang bagus yang sudah distandardisasi oleh BPOM lalu mencakup sterilisasi dari bahan baku media produksi seperti alat-alat dalam menggoreng sampai pada wadah menaruh hasil produksi tersebut serta makanan tersebut sampai pada tingkat kehalalan bahan baku tersebut yang sudah terjamin halalnya oleh MUI.

b. Karyawan yang sehat

Sebelum melakukan produksi hal yang dilakukan karyawan adalah melakukan protokol kesehatan dalam memproduksi bahan makanan protokol kesehatan diterapkan dengan tujuan supaya makanan yang diproduksi nanti terbebas dari bakteri, bakteri sampai pada terbebas dari virus Covid-19. Hal yang pertama dilakukan adalah sebelum karyawan itu masuk ke tempat produksi maka dilakukan pengukuran tubuh di mana pengukuran tubuh ini dilakukan untuk melihat apakah ada demam atau tidak yang terjadi pada karyawan itu, batas suhu tubuh maksimal yang diperkenankan boleh bekerja adalah $37,3^{\circ} \mathrm{C}$ jika ternyata suhu tubuh lebih besar dari itu maka karyawan tersebut diperkenankan untuk kembali ke rumah sampai suhu tubuh menjadi normal, lalu dan dinyatakan sehat. c. Mencuci tangan sebelum memegang bahan baku

Diwajibkan bagi karyawan dalam melakukan proses produksi sebelum memegang bahan baku untuk membersihkan tangan terlebih dahulu menggunakan sabun dan air yang mengalir selama 20 detik, karyawan juga boleh mencuci tangan menggunakan handsanitizer

d. Menggunakan masker dalam produksi

Karyawan diwajibkan untuk menggunakan masker dilingkungan kerja hal ini juga diterapkan dalam melakukan produksi di mana karyawan wajib menggunakan masker dengan tujuan supaya makanan terhindar dari droplet air liur di mana saat dia berbicara bias saja droplet air liur itu masuk ke dalam bahan dasar yang akan diproduksi sehingga untuk menghindari itu semua maka diwajibkan untuk menggunakan masker dalam produksi.

e. Menggunakan seragam kerja yang bersih

Diwajibkan bagi karyawan untuk segera mengganti baju mereka begitu mereka datang ke tempat kerja dengan seragam kerja yang biasa digunakan di tempat kerja, hal serupa juga dilakukan di bagian produksi di mana seragam yang mereka gunakan harus bersih dan diupayakan harus diganti setiap hari dan pemilik restoran atau mitra harus menyediakan seragam yang bersih setiap harinya bagi karyawan.

f. Melakukan disinfektan

Mitra wajib menghimbau kepada seluruh karyawan produksi untuk melakukan disinfektan pada setiap alat produksi yang digunakan dalam melakukan produksi atau mencuci setiap alat produksi menggunakan sabun khusus baik sebelum digunakan maupun setelah digunakan hal ini dilakukan supaya tidak ada bakteri atau virus yang menempel pada alat produksi tersebut

\section{Pelatihan Pengemasan}


Teknik Pengemasan makanan yang dilakukan oleh mitra kepada pelanggan haruslah baik dan aman sehingga tidak terkontaminasi oleh virus Covid-19. Lalu bagaimana cara pengemasannya? Kemasan itu harus steril dan ramah lingkungan, misal terbuat dari bahan kertas yang mudah diurai. Pengemasan dilakukan secara berlipat ganda atau double packing di mana kemasan utama berisi bahan yang dijual lalu dikemas lagi di kemasan yang kedua sehingga nantinya kemasan yang pertama akan bebas dari bakteri maupun virus Covid-19.

\section{Pelatihan Pelayanan di tempat}

Protokol kesehatan juga diterapkan dalam pelayanan di tempat misalnya di luar tempat usaha selalu disediakan air tempat keran air beserta dengan sabun dan mereka juga bias mengganti dengan handsanitizer di depan pintu masuk. Pelayan diwajibkan untuk menggunakan masker dan sarung tangan dalam melayani pelanggan dan jika ada face shield maka wajib digunakan sebelumnya pelayan pada saat masuk kerja wajib mengukur suhu tubuh mereka dan diwajibkan untuk mencuci tangan dengan sabun, protokol selanjutnya adalah membuat partisi pada kasir dan pada etalase tempat order makanan tersebut, membuat batasan jaga jarak juga digunakan sehingga nanti pengunjung dalam memesan bisa menjaga jarak, pembuatan jaga jarak ini bias menggunakan lakban berwarna hitam
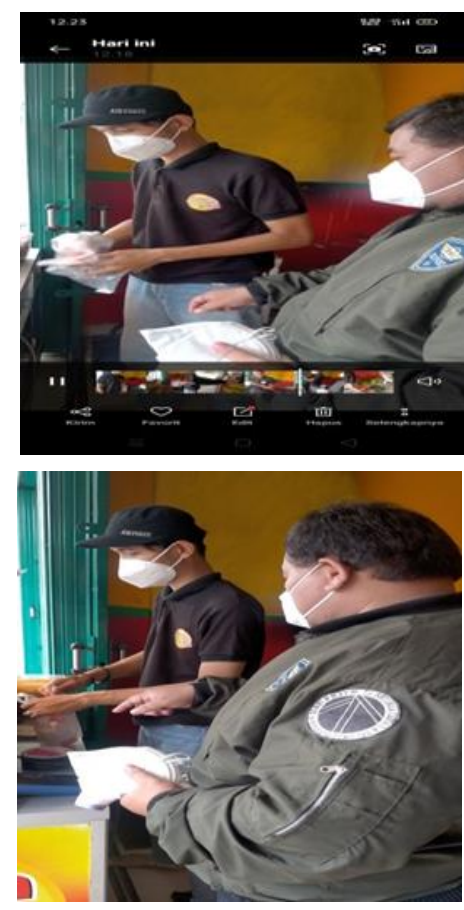
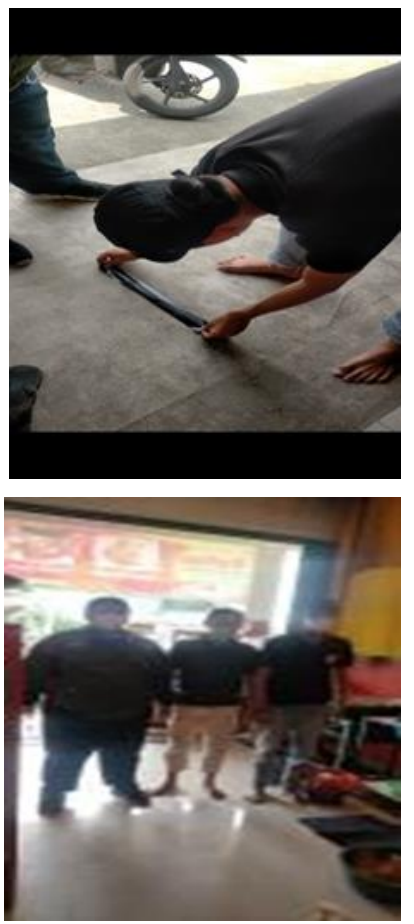

Gambar 1. Pelatihan pelayanan

\section{SIMPULAN}

Sebagai upaya pencegahan penyebaran Covid-19 di sarana produksi dan distribusi, semua aspek mencakup sanitasi, higiene dan kesehatan personel, juga pembatasan jarak fisik, harus diterapkan khusus pada kondisi darurat wabah Covid19, yang ditetapkan pemerintah sebagai masa tanggap kedaruratan kesehatan masyarakat. Pelaku usaha didorong untuk memberikan edukasi dan fasilitasi bagi karyawannya untuk dapat menerapkan aspek tersebut agar upaya pencegahan dan 
Vol. 2, No. 2,

July, 2021,

pp. $97-105$

e-ISSN:

2722-2004

\section{Marketing}

and

Production

Training and

Distribution

\section{of Food}

during

Pandemic

Covid-19 in

Food

Franchise

Business in

Depok Area of

West Java

Syahrudi,

A. A. Wahbi penjaminan keamanan, mutu, dan gizi pangan dapat diwujudkan. Pedoman ini akan diperbaharui sesuai perkembangan ilmiah dan kebutuhan terkini sebagai upaya pencegahan penyebaran Covid-19.

Disarankan dengan terbitnya pedoman ini, pelaku usaha dapat menerapkan dengan baik sehingga dapat mencegah penyebaran Covid-19, dan penjaminan keamanan dan mutu pangan olahan dapat terus ditingkatkan. Ucapan terima kasih kepada seluruh pihak yang telah membantu dalam penyusunan pedoman ini dan semoga pedoman ini dapat bermanfaat bagi seluruh pihak.

\section{DAFTAR PUSTAKA}

Badan Pengawas Obat dan Makanan RI surat edaran No. HK 02.02.1.2.04.20.12 tahun 2020 tentang Upaya Menjaga Ketersediaan Obat dan Makanan Berkualitas pada Masa Status Keadaan Tertentu Darurat Bencana Wabah Corona Virus Disease 2019 (Covid-19) di Indonesia.

Bangsawan, S. (2016). Manajemen Pemasaran Usaha Kecil. Yogyakarta: Graha Ilmu

Dessler, G. (2003). Human Resource Management. Jilid I. Terjemahan Tim Indeks. Jakarta: Indeks Kelompok Gramedia.

Ghozali. (2005). Perencanaan dan Pengembangan Sumber Daya Manusia. Jakarta: Universitas Unindra.

Handoko, T. H. (2011). Manajemen Personalia dan Manajemen Sumber Daya Manusia. Yogyakarta: BPFE Yogyakarta.

Malayu, H S P. 2001. Manajemen Sumber Daya Manusia Dasar dan Kunci Keberhasilan. Jakarta: Bumi Aksara.

Malayu, H.S.P. (2011). Manajemen, Dasar, Pengertian, dan Masalah. Jakarta: Bumi Aksara

Shim, T. A. (2003) Periklanan Promosi, Aspek Tambahan Komunikasi Pemasaran Terpadu. Jakarta: Erlangga 